\title{
Belittled Peasants at Gqumahashe Village, Alice District
}

\section{Mzwandile Paul Komanisi}

Faculty of Social Sciences and Humanities, Department of Sociology and Anthropology, University of Fort Hare

E-mail:mkomanisi@ufh.ac.za

\section{Doi:10.5901/mjss.2014.v5n10p630}

\section{Abstract}

This paper seeks to investigate why female peasants at Gqumahashe are undervalued although farming is currently fundamentally carried out by them. The paper used qualitative research method in order to get at the central experience of informants and chronicle their actions in great detail, regarding their beliefs, history and context. Data was collected by means of participant observation and unstructured interviews. The results of the paper suggest that the fact that female peasants are underestimated, although they are key producers, can be attributed to the fact that they are overlooked in land distribution. Strangely, even though these rural women play an incredible and essential role in farming, they are traditionally undervalued and undercounted. The paper reveals that owing to gender imbalances, women have not been granted prospects to farm more intensively. This study concludes that rural women peasants warrant better glory and greater indebtedness of their palpable contributions towards agriculture, rural development and food security. The overall conclusion of this paper is that if we are to better recognizing women as integral in farming activities, it is critical to ensure gender balance. Once gender imbalances are addressed, a contribution of women in farming will be augmented. On the other hand, agricultural production will advance and the levels of poverty in rural areas will be alleviated.

Keywords: belittled, female peasants, custom, gender imbalance, agricultural production.

\section{Introduction}

Several scholars (Charles, 2010; Claassens \& Cousin, 2008; Todaro \& Smith 2009; Kottak, 2008; Englert, 2008; World Bank 2006; Wanyeki, 2003, Boserup, 1970) concur that the involvement of female peasants in agriculture play a tremendous role in agricultural production. Female peasants are generally viewed as the mainstream of the world's food producers. Furthermore, many horticultural societies, where women are predominantly visible in agricultural activities, assign a major productive role to women (Kottak, 2008, p.366).

To further corroborate the preceding sentiment, Todaro \& Smith (2009, p. 450) explicate that: "A major and until recently often overlooked feature of agrarian systems, particularly in Africa and Asia, is the crucial role played by women in agricultural production. In Africa, where subsistence farming is predominant and shifting cultivation remains important, nearly all tasks associated with subsistence food production are performed by women." In her pioneering work on women and development, Ester Boserup (1970), examined many studies on African women's participation in agriculture and found that in nearly all cases recorded, women did most of agricultural work. In some cases they were found to do around $70 \%$ and in one case nearly $80 \%$ of the total (World Bank, 2006).

Drawing from the above, this paper is therefore aimed at examining gender-based imbalances that make women peasants to be undervalued at Gqumahashe village, in Alice District. The focus is on women's limited access to land.

\section{Methodology}

\subsection{Research Design}

The data presented here was obtained by means of primary (field research) data collection. This study used a qualitative research method as a system of inquiry which seeks to build a holistic, largely narrative, description to inform the researcher's understanding of a social or cultural phenomenon (Hale, 2009; Terre Blanche, Durrheim \& Painter, 2009). The researcher used qualitative research strategy because he sought to focus on witnessing and define the actions of informants as they occurred. The primary objective was to capture a thick description of the informants' everyday behavior in terms of their beliefs, history and context.

\subsection{Data Collection Methods}

Data was gathered by means of participant observation and semi-structured interviews. Havilland, Prins, Walrath \& McBride (2011, p. 324) assert that: "Once in the field, anthropologists rely on participant observation- a research method in which one learns about a group's behaviours and beliefs through social involvement and personal observation within 
the community, as well as interviews and discussion with individual members of the group over an extended stay in the community". The logic behind the use of participant observation was for the researcher to become involved in the everyday life of the informants and to understand the human behavior of the study population in totality. Participant observation was done with the consent of the informants as a measure of avoiding interrupting any activities of the day.

Semi-structured interviews were deemed appropriate for data gathering process among the local female farmers, because it facilitates an open interview that enables the subject to speak (Babbie \& Mouton 2007, p.291). This technique provided the researcher an opportunity to pose questions in an open ended manner. All the interviews with informants were audiotaped and later transcribed. The primary purpose for using interviews was to obtain data on what people think or feel.

\subsection{Sampling}

In their recent book, "The Practice of Social Research", Earl Babbie and Johann Mouton suggest that "sometimes it's appropriate for you to select your sample on the basis of your own knowledge of the population, its elements, and the nature of your research aims: in short based on your judgment and the purpose of the study" (Babbie and Mouton 2010, p. 166). This understanding, in selecting a sample, is the approach the writer used in this study. Babbie and Mouton (2010) term this sampling method a "Purposive or judgmental sampling."

The researcher selected research participants who seemed to have knowledge on agricultural practices, retired farmers and community elders who would be willing to co-operate. In judgmental sampling research participants may be selected according to a number of criteria established by the researcher such as their status, age, gender and occupation or previous knowledge that endows them with special knowledge.

\subsection{Data Analysis}

The field notes that were taken during participant observation, and semi-structured interviews were important in analyzing a qualitative data. Impression of each interview or observation was added to the record during data collection. This means that data was analyzed as it was collected and the analysis continued on an ongoing process. Basically, the job was to find the main themes in the data and to see where evidence leads. The aim was to gain an understanding of what was happening at the study area and why it was happening. This method is referred to as 'content analysis.'

In line with the foregoing proposition, Palmquist (1993) in Babbie and Mouton (2010, p. 491), define content analysis as a research method which "examines words or phrases within a wide range of texts, including books, book chapters, essays, interviews and speeches as well as informal conversation and headlines. By examining the presence or repetition of certain words and phrases in these texts, a researcher is able to make inferences about the philosophical assumptions of a writer, a written piece, the audience for which a piece is written, and even the culture and time in which the text is embedded".

\section{Theoretical Orientation}

The main source of theoretical stimulation for this paper is grounded on the feminist perspective put forward by Esther Vivas in her article; ' Without women there is no food sovereignty', in which she explicates that access to land is not a guaranteed right for many women. Her concept of land rights underpinned this study. Vivas (2012) highlights that in many Southern countries laws inhibit this right, and in countries where lawful access happens there are frequently traditions and practices that preclude women from asset right. Her reasoning inspired the researcher to examine women's exclusion from land ownership on the basis of gender at Gqumahashe village. The researcher has also drawn understanding from the recent work of Fraser (2009). The findings of his study in Cambodia suggest that though it is not unlawful to possess land, the cultural norm prescribe that they do not own land; while are in charge for farm output and agronomy, women have no say over land transaction or how it is transferred to children.

\section{Results of the Study}

Generally, the most fundamental challenge faced by female peasants is the question of legitimate access to land. Universally, female peasants suffer considerable discrimination; they are marginalized to the benefit of men. Historically, almost comprehensively in sub-Saharan Africa, women's rights to land were, and are still inhibited, despite their farreaching contribution in all dimensions of agricultural production. Women's direct access to land is influenced by law and then through custom. This line of argument can be likened to the situation of Gqumahashe. This is the situation prevailing at Gqumahashe Village as well. Female peasants are the main producers at Gqumahashe, yet their access to land is 
constrained by land rights and customs, they are belittled. The argument of the researcher here is that female peasants at Gqumahashe, as elsewhere in the world, are not immune to gender imbalances based on customs. At Gqumahashe, as elsewhere in the world, land is the most essential resource, because a very large proportion of people depend on it for cultivation and therefore their livelihoods.

During the sojourns of the researcher to Gqumahashe, his interest when he conducted interviews was on how land rights in the study area hindered female peasants from land ownership on the basis of gender. The data collected from all informants during the research proved that customary law was a determining factor in the acquisition of land at Gqumahashe, as it is elsewhere in the world. This assertion is reinforced by the findings of Caroline Sweetman (1999) in her work; 'Women, land and agriculture'.

In 1999, Caroline opined that "women's relationship with land is determined by customs and laws of inheritance and marriage" $(1999$, p. 3). Tuyizere (2007) reiterates this reasoning in broad terms by asserting that in traditional African society, women cannot own property. In 2003, Wanyeki observed in Cameroon that "women are disqualified from the management of land because of gender-based labour divisions existing in customary and/ or traditional communities" (2003, p. 55). In contrast, Rural Development Institute (RDI) reported in 2007 that in some regions, particularly in matrilineal societies, customary law can offer superior defense for women's rights and access to land than new legitimate structures that endorse land rights, even these structures endeavor to mirror women's rights and necessities.

When asked about the African perspective on land ownership, one informant had to say:

In African culture, women do not have a right to own land; it is held and used on a family, lineage or clan basis.1 This lineage has a certain right to its use and is responsible for its care. According to our culture, women may not acquire any rights over land. They cannot deal in land in any manner. Land is held in a man's name and passed to the next generation through a male line of inheritance. The eldest son of the man succeeds his father upon his death. He immediately administers all lands that were previously under the control of his father'.

In addition, informant went on to claim that customary law is flexible. It makes a provision for widowed and unmarried women. He highlighted that, under customary law, after the death of a husband, a widow who does not have any heir has the legitimate right to cultivate the land previously owned by her husband. According to this informant, middle-aged unmarried women are entitled to plots of land. Parents who have female children transfer their land rights to their male relatives. This implies that the land does not necessarily belong to the family of the deceased, in particular, female children of the deceased. All informants interviewed during the research acknowledged that, although African culture stipulates that access to land is determined by men, culturally, women have indirect access to land through their relationship-by blood ties or marriage-with men. The responses from all local female peasants interviewed suggested that women who do not own land resort to joint ownership with their husbands or other family members.

Fieldwork evidence indicates that under customary law, land was, and is still "owned" collectively. A particular group of people, lineage, has certain rights to use and control a certain land (cf. Claassens \& Cousins 2011, p.111). Usually, some land remains for collective use and is never identified with an individual. There are common pastures, village common areas, and certain water and forest areas available to all. Informants told the researcher that standalone peasants are granted permission to use specific plots in order to grow certain crops. This individual peasant is warned from the onset that she could be asked to stop cultivating the land at any time. Informants highlighted that, which was in line with African culture which prescribes what kind of crops one should grow. They reported that, those are usually periodic harvests with small life span, because land is ploughed for a small period. When that individual peasant retires from the cultivation of the land, the land returns to the collective group for use by another independent farmer. ${ }^{2}$

By contrast to the foregoing argument, Wanyeki (2003) found that in the Beti region (Cameroon), women's land rights are limited to user rights (2003, p. 55). He proceeds to assert that 'women are allowed user rights on their fathers' or spouse's land. However, these rights are precarious in that they can be lost in cases of divorce or widowhood. For example, once a woman is married, she no longer has access to father's land, except if she breaks her marital ties and only if her father agrees to reinstate her user rights on his land" (Wanyeki 2003, p.55).

Cross \& Friedman in Shamin (1997) conclude differently from the preceding avowal, they reason that "ordinarily, neither single women nor single men are allowed to hold land, so that only married couples have full social citizenship through land rights. These restrictions protect the fabric of rural society by ensuring that only 'proper households, based on marriage, and containing both parents and children, will make up the citizenship of the community. Single people do not obtain citizenship status until they marry and obtain land"(Shamin, 1997, p. 25).

${ }^{1}$ Lineage refers to a descent group which is generally defined as a group of persons who trace descent from a known common ancestor: patrilineal if decent is traced through males only, matrilineal if through females only.

2 Fieldwork observation and interviews-June 2010 


\section{Discussion}

The study has revealed that household food and nutrition security at Gqumahashe relies heavily on female farmers. Particularly striking, these female farmers are faced with constraints. One of the dominant factors militating against women in their participation in agricultural production is land ownership. Land ownership at Gqumahashe is one of the most sensitive political issues. It is clear that the present system of land ownership and size of land holding is a limiting factor in changing from subsistence agriculture to commercial farming. The historical exclusion of women from access to land ownership set the stage for women's limited access to farm land at present. Female peasants at Gqumahashe have access to land through a relationship, either through a husband or her brothers.

Data shows that only men may prescribe a woman's access to land, because in terms of customary law only men have proprietorship and authority over family land. When asked about the reasons for the gender-based imbalances, informants had this to say:

'We restrict women's access and control over land because they do not produce for the market, for cash or export sales. They produce for family consumption.'

Fieldwork evidence indicates that due to limited access to land, local female peasants operate at subsistence level, smallholder level, with intensive agriculture being uncommon. Some cultivate land under a share-cropping basis. ${ }^{3}$

Research findings prove that women's marginalization from land ownership limits access to credit, capital and other resources, thereby effectively barring them from commercial agriculture. The study also reveals that limited rights or access to land further limits livelihoods options and aggravate financial pressure on women, especially in women-headed families. Yet, land ownership continues to be the most crucial form of collateral for credit, and it is a pre-requisite for participation in cooperative organizations.

\section{Recommendations}

Based on the significance of women to household food security and how the arrangement of access to land thwarts their capability for agricultural output and income generation, there is a need for a re-assessment of property ownership as well as legacy customs and practices.

If we are to better recognizing women as integral to agricultural development, it is critical to ensure gender balance. Class and sex discrimination can be rectified if committed government through its extension of credit program makes provision to ensure loans for women are available.

Empowering female peasants at Gqumahashe with landholding rights would go a long way towards achieving equity at Gqumahashe agricultural sector.

If we are to better recognize women as integral in farming activities, it is critical to ensure gender balance. Once gender imbalances are addressed, a contribution of women in farming will be augmented. On the other hand, agricultural production will improve and the levels of poverty in rural areas will be alleviated.

\section{References}

Babbie, E., \& Mouton, J. (2010). The practice of social research. Cape Town: ABC Press.

Boserup, E. (1970). Women's role in economic development. London: George Allen \& Unwin.

Charles, T. (2010). Women's land rights and the challenge of patriarchy: Lesson from Ozall community, Edo State, Nigeria. Gender and Behaviour 8 (1), $2603-2617$.

Claassens, A., \& Cousins, B. (2008). Land, power and custom. Claremont: UCT Press.

Englert, B. (Ed). (2008). Women's land rights and privatization in Eastern Africa. Dar es Salaam: E\& D Vision Publishing Ltd.

Frazer, A. (2009). Agriculture for development. London: Oxfam International.

Hale, L. R .(2009). Qualitative research design. (Online). Available:http://=Rqualitative.net/ir/9-1/research166 (May 17, 2012).

Havilland, W., Harald, P., Walrath, D.,\& McBride, Bunny.( 2011). Anthropology: The human challenge. (13 ${ }^{\text {th }}$ ed). Canada: Dovetail Publishing Services.

Kottak, C. P. (2008). Anthropology: The exploration of human diversity. New York: McGraw-Hill.

Rural development institute.2007.

Shamin, M. (Ed). (1997). Women, land and authority. Cape Town: Creda Press.

Sweetman, C. (1999). Women, land and agriculture. Oxford: Kumarian Press.

Terre Blanche, M., Durrheim, K., \& Painter, D. (Eds). (1999). Research in practice. (2nd ed). Cape Town: University of Cape Town Press.

Todaro, M., \& Smith, S.C. (2009). Economic development. Essex: Pearson Education Limited.

Tuyizere, A. P. (2007). Gender and development: The role of religion and culture. Kampala: Fountain Publishers.

Vivas, E. (2012). Without women there is no food sovereignty. (Online) Available: http://www.resilience.org/stories (April 18, 2013).

Haviland, A., Pinns,H., McBride, B., \& Walrath, D. (2011). Anthropology: The human challenge. (13 ${ }^{\text {th }}$ ed). Wadsworth: Cengage Learning.

Wanyeki, M. L. (Ed). (2003). Women and land in Africa. Cape Town: David Philip Publishers.

World bank. (2006).

${ }^{3}$ Sharecropping occurs when a peasant cultivates the landowner's land in exchange for a share of food output. The landowner's share varies from less than a third to more than two-thirds of output. 